\begin{tabular}{|c|c|c|c|c|c|c|}
\hline \multirow{4}{*}{ Impact Factor: } & ISRA (India) & $=3.117$ & SIS (USA) & $=0.912$ & ICV (Poland) & $=6.630$ \\
\hline & ISI (Dubai, UAE & $=0.829$ & РИНЦ (Russia & $=0.156$ & PIF (India) & $=1.940$ \\
\hline & GIF (Australia) & $=0.564$ & ESJI (KZ) & $=8.716$ & IBI (India) & $=4.260$ \\
\hline & JIF & $=1.500$ & SJIF (Morocco & $=\mathbf{5 . 6 6 7}$ & OAJI (USA) & $=0.350$ \\
\hline
\end{tabular}

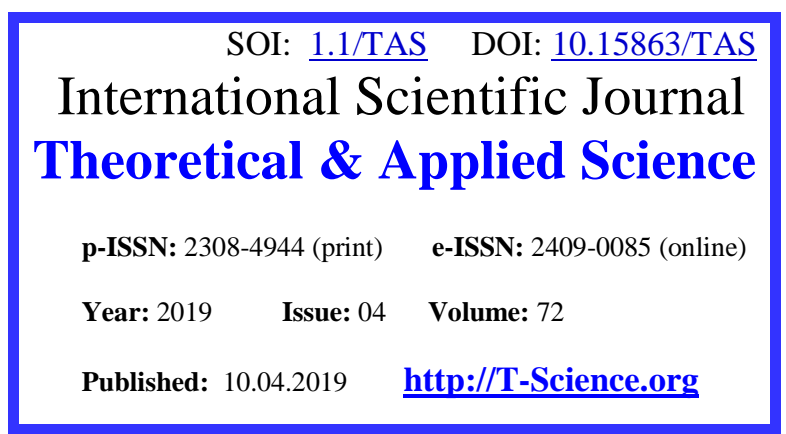

SECTION 31. Economic research, finance, innovation, risk management.
QR - Issue

QR - Article

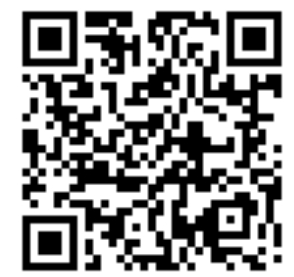

Gauhar Sarsenbaevna Borankulova TarSU them. M.H.Dulati Ph.D., i.o.dotsent b.gau@mail.ru

Zhansaya Ahmet TarSU them. M.H.Dulati undergraduate specialty "Information Systems" r.d.akhmetova@mail.ru

\title{
DEVELOPMENT OF THE BANKING SYSTEM OF KAZAKHSTAN
}

Abstract: The article discusses the development and implementation of innovative banking services, the target function of managing bank liquidity, which is to maximize profits while complying with the economic standards set and determined by the bank itself.

Key words: Bank business, economy.

Language: English

Citation: Borankulova, G. S., \& Ahmet, Z. (2019). Development of the banking system of Kazakhstan. ISJ Theoretical \& Applied Science, 04 (72), 66-70.

Soi: http://s-o-i.org/1.1/TAS-04-72-11 Doi: crossef https://dx.doi.org/10.15863/TAS.2019.04.72.11

\section{Introduction}

One of the most important financial and economic tasks in Kazakhstan is the creation and maintenance of stable, flexible and efficient banking infrastructure. In addition to purely economic difficulties added social: constantly changing the legal framework; rampant crime in the country, as a resultthe desire of mafia structures to take over such a highincome in terms of inflation, as banking; the desire of most bankers to get a momentary profit, as a result the development of only one area of activity, which leads to threats of bankruptcy of individual banks and the crisis of the banking system as a whole.It is not enough just to announce the creation of new credit institutions it is necessary to study the peculiarities of foreign practice to restore the lost rational principles of functioning of credit institutions adopted in the civilized world and based on the centuries-old experience of market financial structures.

\section{Materials and Methods}

Today's Kazakhstan's economy crisis processes significantly complicate the situation in the banking sector of Kazakhstan. There is a reduction in the possibility of obtaining reliable profits as a result of serious financial difficulties of banking partners and customers, the crisis of non-payments complicates the situation of banks, and the least stable of them lead to bankruptcy.The credibility of financial institutions is undermined by the fraud of the population. It should also be noted that inflation surges, forecasts of instability growth, weak predictability of state economic policy increase the risk not only of production investments but also of any long-term processes.

But at the same time, the largest banks accumulate a certain potential for financing projects in priority sectors, the creation of strategic financial and industrial alliances as "locomotives" of the Kazakh economy, it should be noted the increased interest of large banks to invest in economically necessary or original and competitive at the world level of production.

The strategic directions of development of the banking sector of Kazakhstan were the expansion of the network of branches throughout the country, the establishment of relations with banking institutions abroad, the desire to enter the financial markets of Asia. The dynamism of changes in the banking sector is growing, due to the instability of the credit market, the strengthening of interbank competition, stratification among banking institutions.

Ultimately, banking affects the expectations, feelings and plans of specific people. Banks seeking to survive in today's competition should strive to ensure that the aspirations of its customers become a reality. The main objective of the components of the basis on which the funds of shareholders and 


\begin{tabular}{|c|c|c|c|c|c|c|}
\hline \multirow{4}{*}{ Impact Factor: } & ISRA (India) & $=3.117$ & SIS (USA) & $=0.912$ & ICV (Poland) & $=6.630$ \\
\hline & ISI (Dubai, UAE & $=0.829$ & РИНЦ (Russia) & $=0.156$ & PIF (India) & $=1.940$ \\
\hline & GIF (Australia) & $=0.564$ & ESJI (KZ) & $=8.716$ & IBI (India) & $=4.260$ \\
\hline & JIF & $=1.500$ & SJIF (Morocco & $=5.667$ & OAJI (USA) & $=0.350$ \\
\hline
\end{tabular}

customers are saved and multiplied is the reliability of the Bank.

The mechanism of improvement of the banking system of Kazakhstan begins to function, and only if it will take the whole society: the bankers, the state, and the press, and the population - we will get fast and positive results.

The development of banks and commodity production and circulation has historically been parallel and closely intertwined. At the same time, banks, conducting monetary settlements, lending to the economy, acting as intermediaries in the redistribution of capital, significantly increase the overall efficiency of production, contribute to the growth of productivity of public labour.

Under the conditions of developed commodity and financial markets, the structure of the banking system is becoming increasingly complex. There are new types of financial institutions, new credit instruments and methods of customer service.

Banks are looking for the most optimal forms of the credit system, an effective mechanism in the capital market, new methods of servicing commercial structures. Banks ensure the life of the economy while remaining out of sight of the masses. But do not forget about their problems and needs that need to be addressed and provided. Changing the activities of banks will create favourable conditions for the development and operation of the banking system - a necessary component for the effective operation of market mechanisms.

A special place in the development of the banking system of Kazakhstan is given to the Halyk Bank, its development strategy. Strengthening its position as" the best provider of financial services in the market of consumer and corporate banking in Kazakhstan " is the main task of Halyk Bank. This determines the fact that the Bank needs to fulfil its obligations to the public sector, serving a large number of the population of Kazakhstan, putting commercial goals on a par with its privatization program. The Bank's ability to maintain this balance sheet is crucial to its success.

In order to adapt to the growing needs of customers and the external environment, with the development of banking activities in Kazakhstan, banks faced the task of diversifying the portfolio of banking services through the introduction of innovative banking services. Innovative lever through which banks are moving in difficult market conditions to the planned strategic boundaries is the use of innovative banking services is considered by them as.

The development and implementation of innovative banking services in Kazakhstan require high costs for banks to implement changes, all this is determined by the following factors: institutions;
- the continuous movement of entrepreneurial thought;

- Kazakhstan's accession to the WTO;

- integration into the EurAsEC;

- integration of the banking system into the European Union;

- tightening regulation of second-tier banks;

- increasing the size of domestic banks;

- risk diversification based on the correlation between cash flows from innovative banking services and the movement of existing banking services;

- cooperation of Kazakh banks with the world's largest banks;

- penetration of foreign banks in the Kazakh banking market;

- development of information and other technologies.

The situation today in the banking sector of Kazakhstan is quite twofold. If we look at the statistics for the last years, we can note the growth of all indicators in a positive direction. Despite this, our banking system and each Bank individually are not yet ready for the upcoming changes in the near future. We can also note the accession of Kazakhstan to the WTO, the transition from Basel-2 to Basel 3, the increasing integration of our country, the economy and the banking system in the global economic architecture in the context of globalization.

It is possible to present the following recommendations contributing to increasing the liquidity and solvency of the Bank, which was at the limit of its liquidity, and this is possible due to errors in his policy, underestimation of the market, shortcomings in the analytical work and other reasons, and who is forced to resort to urgent measures.

First, a Bank with an unstable situation can be advised to improve the organizational structure of the Bank, that is, to pay attention to the development of management, in particular, to create, for example, an internal audit service, which would reduce abuse within the Bank.

Secondly, the Bank needs to assess the liquidity of the balance sheet by calculating liquidity ratios. In the process of analysis of the balance sheet on liquidity may be identified deviations in the direction of both reducing the minimum allowable values and their significant excess. In the first case, banks need to bring liquidity indicators in line with regulatory values within a month. This is possible due to the reduction primarily of interbank loans, accounts payable and other types of attracted resources, as well as by increasing the Bank's own funds. however, it should be borne in mind that raising additional capital in the form of issuing new shares will cause a reduction in dividends and disapproval of shareholders.

On the other hand, for the Bank, like any other enterprise, the General basis of liquidity is ensuring the profitability of production activities (operations). 


\begin{tabular}{|c|c|c|c|c|c|c|}
\hline \multirow{4}{*}{ Impact Factor: } & ISRA (India) & $=3.117$ & SIS (USA) & $=0.912$ & ICV (Poland) & $=6.630$ \\
\hline & ISI (Dubai, UAE & $=0.829$ & РИНЦ (Russia) & $=0.156$ & PIF (India) & $=1.940$ \\
\hline & GIF (Australia) & $=0.564$ & ESJI (KZ) & $=8.716$ & IBI (India) & $=4.260$ \\
\hline & JIF & $=1.500$ & SJIF (Morocco & $=5.667$ & OAJI (USA) & $=0.350$ \\
\hline
\end{tabular}

Thus, if the actual value of the main regulatory liquidity ratio is much greater than the minimum allowed, the activities of such a Bank will be negatively assessed by its shareholders, in terms of unused opportunities for profit.In this regard, it should be noted that the analysis of the balance sheet liquidity should be carried out simultaneously with the analysis of the Bank's profitability. the experience of banks shows that banks receive more profit when they operate on the verge of the minimum acceptable values of liquidity ratios, i.e. fully use the rights to raise funds as credit resources.

At the same time, the peculiarities of its work as an institution based on the use of clients' funds dictate the need to apply liquidity indicators. Maximum liquidity is achieved by maximizing cash balances and correspondent accounts in relation to other assets. But in this case, the Bank's profit is minimal. Profit maximization does not require the storage of funds, but their use for loans and investments. Because of this, you should minimize the cash on hand and balances on correspondent accounts to a minimum, profit maximization threatens the continuity of the Bank fulfilling its obligations to clients.

Therefore, the essence of Bank liquidity management is a flexible combination of opposite liquidity and profitability requirements. The objective function of the Bank's liquidity management is to maximize profits, subject to mandatory compliance with the economic standards established and determined by the Bank itself.

Third, the Bank should determine the need for liquidity at least for the short term. As already noted, this need can be predicted in two ways. one involves an analysis of the credit needs and expected level of deposits of each of the leading clients, and the other involves forecasting the volume of loans and deposits. both methods have a drawback: they are based on the average, not the maximum level of liquidity. This may be sufficient to assess the liquidity of the banking system as a whole, but it will not tell the management of the individual Bank what its cash flow should be next week to cover the withdrawal of deposits and loan applications. Only an analysis of the accounts of individual customers of the Bank will allow it to determine the cash needs at the moment.

The preliminary study of economic and financial conditions in the local market, the specifics of the clientele, opportunities to enter new markets, as well as the prospects for the development of banking services, including the opening of the Bank, will also help to solve this problem new types of accounts, conducting transactions by the trust, leasing, factoring, etc. And, in addition to local factors must also be considered and nationwide. For example, changes in monetary policy, legislation, etc..

The study of all this, as well as forecasting, will help the Bank to more accurately determine the necessary share of liquid funds in the Bank's asset. At the same time, the Bank should rely on its experience.

Based on the predicted value of the required liquid funds, the Bank needs to form a liquid reserve for the performance of unforeseen obligations, the appearance of which may be caused by changes in the state of the money market, the financial position of the client or the partner Bank.

Fourth, maintaining liquidity at the required level is carried out by means of a certain policy of the Bank in the field of passive and active operations, developed taking into account the specific conditions of the money market and the characteristics of the operations. That is, the Bank should develop a competent policy for managing active and passive operations.

In this case, in asset management, the bank should pay attention to the following issues:

1. Cash management should be more efficient, there is no need to plan for cash income and cash flow, as well as to develop payment schedules.

2. Periods to which the bank allocates funds must meet the requirements of the resources attracted. We do not allow the excess of cash in the accounts of the asset over cash in the liabilities accounts.

To focus on increasing the profitability of work for the efficiency and in the range of individual operations in particular. So in the management of credit portfolio, it is essential to:

- to refer to the placement of credit properties according to the degree of their risk, to provide for the return of loans, to pay off loans. The credit properties of the bank should be classified according to a number of criteria (level of credit, customer satisfaction, loan reimbursement, loan insurance, etc.). For each group of loans, in the total amount of bank credit ratings and its change serve as a basis for improving the level of the liquidity ratio, show the potential of the previous credit policy of the bank or lack of credit or loss. Grouping of the loans by borrowers is realized with the help of the computer system, which allows controlling the liquidity coefficient level daily and controls to analyse possibilities of the future large loans by the bank independently or by attending in banking consortium.

- analyze the placement of loans in terms of osnoe database. In particular, a method has been developed for analyzing the repayment and presentation of a loan to individual customers and types of loans (a credit card and a credit card) in the next 30 days;

Such an analysis can be done daily, as well as taking into account the data of credit agents who are at the stage of development. The results of the analysis can be used by banks for the efficient solution of the decision to purchase or sell resources. Such an analysis reveals the deep, hidden processes, reveals the trends that occur in the presence of unchanged abilities in the region can cause a fall in the level of 


\begin{tabular}{|c|c|c|c|c|c|c|}
\hline \multirow{4}{*}{ Impact Factor: } & ISRA (India) & $=3.117$ & SIS (USA) & $=0.912$ & ICV (Poland) & $=6.630$ \\
\hline & ISI (Dubai, UAE & $=0.829$ & РИНЦ (Russia) & $=0.156$ & PIF (India) & $=1.940$ \\
\hline & GIF (Australia) & $=0.564$ & ESJI (KZ) & $=8.716$ & IBI (India) & $=4.260$ \\
\hline & JIF & $=1.500$ & SJIF (Morocco & $=5.667$ & OAJI (USA) & $=0.350$ \\
\hline
\end{tabular}

liquidity and solvency of the bank and can give warning to these consequences by putting the key.

- more carefully study the credit borrower;

- to limit the size of the loan, we represent a single borrower with a part of own funds;

- issue loans to a larger number of clients when storing the total

the volume of credit;

- Increase the return of credit, in that way, at the expense of more reliable support;

- take measures to recover outstanding loans and accrued interest for borrowing;

To apply the methods of analysis of the group of settlement accounts in the client and the intensity of the payment account to the bank's corporate account. The results of the analysis also serve as the basis for a reasoned regrouping of assets in the bank's balance sheet.

Change the structure of assets, i.e. increase the number of liquid assets due to the debt repayment, clearing the balance by allocating separate types of activity for the independent balance, increasing own funds, borrowing money from other banks, etc.

Work to reduce the risk of operations. In this case, it is not necessary to remember that urgent measures taken by credit institutions to maintain their liquidity and solvency, as a rule, are connected with the growth of bank expenses and the reduction of their profits. Managing the risks of imbalance of balance and insolvency of the bank reduces the potential losses of the bank, creates a strong basis for their future activities. The risk management system for the imbalance of the balance sheet and the non-payment of the bank is oriented towards the requirements of the national bank of the country to observe the established liquidity and solvency of banks. To recognize the risks of imbalance in the liquidity of the balance sheet and non-payment of the bank, it is necessary to create a special system of daily accounting for the above liquidity indicators, analysis of the factors affecting their change. For this purpose, it is advisable to create a database, which will efficiently generate all the required information to perform analytical work, the Bank's license will be generated on the basis of this information.

As a source of information database creation, we consider credit and deposit contracts, loan contracts from other banks, information on the need of loans, payments terms, a daily summary of the balance of accounts, daily entry of balance of personal accounts, information of off-balance accounts, loss of credit, and etc.

In liabilities management, a bank should be advised:

Apply a method of analyzing the placement of passives in their terms, who is responsible for managing the obligations of the bank, optimizing and changing their structure depending on the level of liquidity ratios, making the weighted policy in the area of accumulation of funds, but not adjusting the funds.

Follow up on the equity of capital attracted.

Analyze the deposit base of the bank:

Pay attention to the structure of deposits: shortterm and savings deposits are more stable than deposits before demand;

Determine a strategy for maintaining the viability of a deposit. A part of this strategy is marketing - improving the quality of customer service so that they would remain loyal to the bank and during times of crisis. The increase in the savings deposits, their average amount also mitigates the deposit losses during times of crisis.

It is not only stability that is considered, but also the source of deposits, that is, deposits of individuals are more reliable than deposits of legal entities, due to differences in the number of contributions.

Bring credit resources accounting accordingly;

Assess the reliability of deposits and loans made by other credit institutions.

To stop the obligations of enforcing when regrouping passives in order to justify them.

In general, to recognize the risks of unbalancing liquidity of balance non-insolvency of the bank requires the creation of a special system of daily control for the level of indicators given in the first and second chapters, analysis of the factors affecting their change. For this purpose, it is advisable to create a database, which will efficiently generate all the necessary information to perform analytical work, the Bank's license will be generated on the basis of this information. For the purposes of the database, the prisoners will be in charge of the settlement of the loans. balance accounts, information about reversing loans, etc.

On the basis of the daily database of banks, the values of indicators of solvency and liquidity should be disclosed and an analysis of the prospects for the development of bank operations taking into account solvency and liquidity should be analyzed. This calls for interconnecting the decision to place funds, attract resources, raise funds for the bank's funds, increase the bank's participation in other enterprises and banks, draw up sources of investment funds and develop new bank operations with demands for funds from the bank's investment funds and develop new bank operations with demands for funds. Reviewing the analysis gives the possibility to foresee various changes in the level of liquidity and solvency of the bank and to take urgent measures to stabilize them.

In international practice, managers of bank liquidity management have developed a number of practical recommendations for improving this type of business. The first of these is done in that the liquidity management managers should cite the activities of all the bank branches that are responsible for using and attracting funds, and coordinate their activities with the activities of these banks. 


\begin{tabular}{|c|c|c|c|c|c|c|}
\hline \multirow{4}{*}{ Impact Factor: } & ISRA (India) & $=3.117$ & SIS (USA) & $=0.912$ & ICV (Poland) & $=6.630$ \\
\hline & ISI (Dubai, UAE & $=0.829$ & РИНЦ (Russia & $=0.156$ & PIF (India) & $=1.940$ \\
\hline & GIF (Australia) & $=0.564$ & ESJI (KZ) & $=8.716$ & IBI (India) & $=4.260$ \\
\hline & JIF & $=1.500$ & SJIF (Morocco & $=5.667$ & OAJI (USA) & $=0.350$ \\
\hline
\end{tabular}

The second recommendation is that liquidity management managers should foresee the largest depositors and users of the bank who plan to withdraw funds from the bank or increase deposits. This directors and managers plan their actions in case of a shortage or surplus of liquidity.

In accordance with the third recommendation, liquidity management managers in cooperation with the seniors and managers of departments mustensure that the priorities and objectives of liquidity management are obvious. In recent years, when placing funds, the liquidity of the bank often had a higher priority. Today, the liquidity management in the General Assembly of the mechanism in comparison with the bank's priority number 1 - the presentation of loans to all categories of clients. The bank has to submit any successful loans, setting the task of the liquidity manager to raise sufficient cash to secure loans.

\section{Conclusion}

The essence of the fourth recommendation is as follows: the suitability of a bank in liquid funds and the decision to "thoroughly" place them should be analyzed in order to avoid both surplus and shortage of liquid funds. Excessive liquidity, which is not reinvested on the same day, leads to the benefits of the bank, while their deficit must be quickly eliminated in order to avoid the unpleasant consequences of unsuccessful loans or delivery of assets that also lead to funds.

Thus, each bank must self-sustainingly ensure the maintenance of its liquidity at a given level on the basis of an analysis of its composition, emerging at specific periods of time, and the prediction of the results of activities and implementations in the next scientific basis of advanced research in the field of charter capital, funds of special purpose of reserves, attraction of borrowed funds of foreign organizations, the implementation of active credit operations.

\section{References:}

1. (2008). Banking: strategic leadership. ed. V. Platonov and M. Higgins (Eds.). Moscow: Consoltbanker.

2. (2012). Bank management: a textbook. ed. E.F. Zhukov (Eds.). (p.319). Unity-Dana.

3. (2010). Banking /ed. Beloglazova G.N. and Krolivetskoy L.P.(Eds). Moscow: Finance statistics

4. (2009). The international financial market / Ed. V.A. Slepova, E.A. Ping (Eds.). (p.34). Moscow: Master.

5. (2012). Banks, non-bank credit organizations and their operations: a textbook. / ed.
E.F.Zhukova, N.D. Eriashvili (Eds.). (p.559). Unity-Dana.

6. Kovzanadze, I. (2000). Kentrul for the activity of the commercial banks and their liquidity. Finance, $N$ 10, 70-71.

7. Solovyeva, S. (2010). Banking system: backstop or a stimulus for the growth of the economy? Finance, $N$ 11, 26-28.

8. Kolesnikov, V. I. (2000). Bankovskoe delo. Moscow: Finansy i statistika.

9. Lavrushin, O. N. (2000). Bankovskoe delo. Moscow: Finansy i statistika.

10. Zhukova, E. F. (1997). Banki i bankovskie operatsii. Moscow: Banki i birz. 